\title{
Selection of Interpolators to Predict Populations of Tibraca limbativentris in Irrigated Rice
}

\author{
Mauricio Paulo Batistella Pasini ${ }^{1}$ \\ https://orcid.org/0000-0002-3538-8397 \\ Eduardo Engel ${ }^{*}$ \\ https://orcid.org/0000-0001-8218-6248 \\ Alessandro Dal’Col Lúcio³
https://orcid.org/0000-0003-0761-4200 \\ Sabrina Lago Dalla Nora ${ }^{1}$ \\ https://orcid.org/0000-0001-9160-4915
}

${ }^{1}$ University of Cruz Alta, Laboratory of Entomology, Cruz Alta, Rio Grande do Sul, Brazil; ${ }^{2}$ University of São Paulo, Luiz de Queiroz College of Agriculture, Department of Entomology and Acarology, Piracicaba, São Paulo, Brazil; ${ }^{3}$ Federal University of Santa Maria, Department of Crop Science, Santa Maria, Rio Grande do Sul, Brazil.

Editor-in-Chief: Paulo Vitor Farago

Associate Editor: Adriel Ferreira da Fonseca

Received: 2018.10.26; Accepted: 2021.05.27.

*Correspondence: agron.engel@gmail.com; Tel.: +55-54-991136200 (E. E.).

\section{HIGHLIGHTS}

- Tibraca limbativentris is one of the main pests on rice crops.

- Its spatial distribution pattern can be studied using a geostatistical approach.

- There was variation in the T. limbativentris spatial structure according to rice phenology.

- The ordinary kriging interpolator performed better in predicting its populations.

Abstract: Kriging is a method that estimates values in places not sampled from different interpolators, therefore, widely used to predict the spatial distribution of organisms. However, the different interpolators may vary in performance depending on the organism under study or the area evaluated. The aimed study to compare the ordinary kriging and inverse of distance weighted interpolation methods, applied to the spatial distribution of population density of Tibraca limbativentris in irrigated rice. This study was carried out in Santa Maria, RS, Brazil, in two fields with areas of 1.3 ha and 6.2 ha, respectively. Seven evaluations of the population density of $T$. limbativentris were carried out, corresponding to the period from sowing to maturation. In these areas the adults of $T$. limbativentris were quantified and the sum used for the statistical and geostatistical analysis. The sample population of $T$. limbativentris was submitted to different semivariograms, which were selected through cross-validation. The sample population of $T$. limbativentris was submitted to different semivariograms, selected by means of cross-validation. Once selected, semivariograms were used in both tested interpolation methods. From the results it was concluded that the ordinary kriging interpolation method performed better in all evaluations performed in both areas. Therefore, we recommend its use for estimating the population density and spatial distribution of $T$. limbativentris in the 
irrigated rice throughout the crop phenology. Using appropriate interpolation methods, localized management can be used, reducing costs for controlling this pest and increasing the sustainability of the environment.

Keywords: precision; Oryza sativa; stink bug; geostatistics.

\section{INTRODUCTION}

Rice (Oryza sativa L.) is one of the most produced and consumed cereals in the world, being the main food for more than half the world population [1]. Brazil is the ninth producer, accounting for approximately $2 \%$ of production, with Rio Grande do Sul state being the state of greatest production, with about one million cultivated hectares corresponding to $60 \%$ of total national production [2].

One of the aspects that undermines the irrigated rice crop is the attack of the stink bug, Tibraca limbativentris Stal, 1860 (Hemiptera: Pentatomidae), being considered the second insect of economic importance [2]. This insect-pest can be found in the vegetative and reproductive phases directly affecting the yield components. When attacking the stems, generating the formation of white panicle or the partial sterility of the spikelets, being this the component of the highest influencing the reduction of yield of rice grains [3].

Populations of insect pests in crops can be estimated using interpolation procedures, which allow the generation of continuous surfaces through point sample units [4]. Between the methods of interpolation, the ordinary kriging and the inverse of distance weighted are more used [5].

The ordinary kriging method uses spatial dependence between neighboring samples, expressed in the semivariogram, to estimate values at any position within the field, with no trend and minimum variance ${ }^{7}$. According to Pires and Strieder [8] kriging is a geostatistical process of estimating the values of variables distributed in space, based on adjacent values when considered interdependent by variographic analysis. In method the inverse of distance weighted, the weighting factor is the inverse of the elevated Euclidean distance to an exponent. According to Miranda [9] this interpolator predicts values for non-sampled locations using weighted linear combination of the points sampled in the vicinity. When it is squared, it is defined as the inverse of the square of the distance between the known point and the estimated point.

These methods, stochastic and deterministic respectively, differ in their estimates and several are the works that confirm this situation. Comparing both methods of interpolation, Júnior and coauthors [10] observed a greater reduction in mean variance and sampling error with the inverse of the square of the distance in relation to ordinary kriging in the stratification of eucalyptus stands. Already Mello and coauthors [7] verified smaller errors in the kriging method for parameters of the intense rainfall equation. In analyzing the spatial distribution of cicadas, Soares and coauthors [11] obtained minimal advantages of ordinary kriging for the inverse method of the distance square. Silva et al. [6] used interpolation methods to represent the spatial variability of soil pH in two treatments in the coffee crop, where kriging presented the lowest standard deviation of the mean of the errors. Souza and coauthors [12] did not verify differences between the two interpolation methods for soil chemical attributes, being considered efficient in the inference of values. Silva and coauthors [6] evaluated interpolators for the monthly precipitation in the State of Espírito Santo, where ordinary kriging presented the best estimates. Guedes and coauthors [13] evaluated the potential of the use of spatial interpolators in Eucalyptus sp. Stands where the use of the inverse interpolator of the distance square generated better estimates. In general, these studies demonstrate the variability of the performance of the interpolators in function of the object of study, making its study necessary.

Choosing the appropriate interpolation method is essential for obtaining reliable spatialization maps, with lower errors in the estimates $[6,7,12,25]$. However, in the vast majority of the works involving regionalized variables with pest insects this is not taken into account, which can often disqualify the presented information for the development of management strategies. Thus, the work aimed to identify the best interpolation method to spatialize the population of $T$. limbativentris in the cultivation of irrigated rice.

\section{MATERIAL AND METHODS}

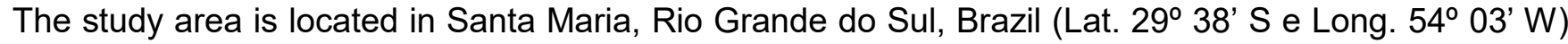
and was divided into two cultivation areas. The first area with 1.3 ha called field 01 and the second with 6.92 ha called field 02. Both areas were cultivated with the irrigated rice culture under the technical recommendations of the crop [2]. In the surroundings, the areas were surrounded by wild vegetation. The local climate according to the Köppen classification is of the Cfa type, subtropical humid, without dry season and with hot summers [14]. During the execution of the research there was no application of pesticides. 
In each cultivation area, a grid of $30 \mathrm{~m} \times 30 \mathrm{~m}$ was generated for the insect-pest sampling, yielding 39 sample units at field 01, and 192 sample units at field 02. In each unit, 200 rice plants were sampled, totaling $1 \mathrm{~m}^{2}$ (50 suitable plants per linear meter and spacing between rows of $0.20 \mathrm{~m}$ ). In each rice plant a direct count of the number of individuals of Tibraca limbativentris. From the sowing, seven evaluations were carried out for each field, according the rice phenological development (Table 1).

Table1. Phenological stages evaluated according to Counce et al. [15]. Santa Maria, RS, Brazil, 2012/2013 harvest.

\begin{tabular}{cl}
\hline Phenological Stage & \multicolumn{1}{c}{ Description } \\
V3 & The collar formed in the 3rd leaf of the main stem. \\
V6 & The collar formed in the 6th leaf of the main stem. \\
V9(R0) & Corresponding to panicle initiation. \\
R2 & Formation of the collar of the flag leaf (rubber). \\
R4 & Corresponding to anthesis. \\
R6 & Elongation of one or more grains in the shell. \\
R9 & In the R9 stage corresponding to the complete maturity of the grains in the panicle.
\end{tabular}

For data analysis, the total number of individuals collected per $\mathrm{m}^{2}$ (200 plants) was used. The adult values of $T$. limbativentris, by evaluation, were analyzed using descriptive statistical analysis (average, standard deviation, coefficient variation, minimum, maximum, sum, asymmetry and kurtosis) and interpolation techniques. In the ordinary kriging interpolator (OK) the data normality hypothesis was tested by the Shapiro-Wilk test at $5 \%$ significance and, when not satisfied, the data that presented positive asymmetry were submitted to Box-Cox transformation.

The data were then submitted to geostatistical analysis to verify the existence of spatial dependence as Pasini et al. [16]. The degree of spatial dependence of the attributes under study was quantified by adjusting the theoretical models to the experimental isotropic semivariograms based on the assumption of stationarity of the intrinsic hypothesis which is estimated by the expression:

$$
\gamma(h)=\frac{1}{2 N(h)} \sum_{i=1}^{N(h)}\left[Z\left(x_{i}\right)-Z\left(x_{i}+h\right)\right]^{2}
$$

where $\gamma$ is the semivariance and $\mathrm{N}(\mathrm{h})$ is the number of pairs of measured values $\mathrm{Z}\left(\mathrm{x}_{\mathrm{i}}\right)$ and $\mathrm{Z}\left(\mathrm{x}_{\mathrm{i}}+\mathrm{h}\right)$ separated by a vector h. From the experimental semivariograms were obtained and adjusted the models of semivariograms [17]: circular,

$$
\gamma(h)=\frac{2 C_{0}+C_{1}}{\pi}\left[\frac{h}{a} \sqrt{1-\left(\frac{h}{a}\right)^{2}}+\arcsin \frac{h}{a}\right]
$$

for $0 \leq \mathrm{h} \leq \mathrm{a}$ e $\gamma(h ; \theta)=C_{0}+C_{1}$ for $\mathrm{a}<\mathrm{h} ;$ Spherical,

$$
\gamma(h)=C_{0}+C_{1}\left[\frac{3}{2} \frac{h}{a}-\frac{1}{2}\left(\frac{h}{a}\right)^{3}\right]
$$

for $0 \leq \mathrm{h} \leq \mathrm{a}$ e $\gamma(h ; \theta)=C_{0}+C_{1}$ for a $<\mathrm{h}$; Tetraspherical,

$$
\gamma(h)=\frac{2 C_{0}+C_{1}}{\pi}\left[\arcsin \left(\frac{h}{a}\right)+\sqrt{1-\left(\frac{h}{a}\right)^{2}}+\frac{2}{3} \frac{h}{a}\left(1-\left(\frac{h}{a}\right)^{2}\right)^{\frac{3}{2}}\right]
$$

for $0 \leq \mathrm{h} \leq \mathrm{a}$ e $\gamma(h ; \theta)=C_{0}+C_{1}$ for $\mathrm{a}<\mathrm{h}$; Pentaspherical,

$$
\gamma(h)=C_{0}+C_{1}\left[\frac{15}{8} \frac{h}{a}-\frac{5}{4}\left(\frac{h}{a}\right)^{3}+\frac{3}{8}\left(\frac{h}{a}\right)^{5}\right]
$$

for $0 \leq \mathrm{h} \leq \mathrm{a}$ e $\gamma(h ; \theta)=C_{0}+C_{1}$ for $\mathrm{a}<\mathrm{h} ;$ Exponential,

$$
\gamma(h)=C_{0}+C_{1}\left[1-e^{-3\left(\frac{h}{a}\right)}\right]
$$

for all h; Gaussian,

for all h; Rational quadratic,

$$
\gamma(h)=C_{0}+C_{1}\left[1-e^{-3\left(\frac{h}{a}\right)^{2}}\right]
$$

$$
\gamma(h)=C_{0}+C_{1} \frac{19\left(\frac{h}{a}\right)^{2}}{1+19\left(\frac{h}{a}\right)^{2}}
$$


for all $\mathrm{h}$; Cardinal sin, 0 for $\mathrm{h}=0$ and

for $\mathrm{h} \neq 0$; $\mathrm{k}$-bessel,

$$
\gamma(h)=C_{0}+C_{1} \frac{1-\sin \left(\frac{2 \pi h}{a}\right)}{\sin \left(\frac{2 \pi h}{a}\right)}
$$

for all $\mathrm{h}$, where $\Omega_{\theta \mathrm{k}}$ is a value found numerically by

$$
\gamma(h)=C_{0}+C_{1}\left[1-\frac{\left(\frac{\Omega_{\theta_{k}} h}{a}\right)^{\theta_{K}}}{2^{\theta_{K}-1} \Gamma\left(\theta_{K}\right)} K_{\theta_{k}}\left(\frac{\Omega_{\theta_{k}} h}{a}\right)\right]
$$

for all $\theta_{k}, \Gamma\left(\theta_{k}\right)$ this gamma function,

$$
\gamma\left(\theta_{k}\right)-0.95\left(C_{0}+C_{1}\right)
$$

$$
\Gamma(y)=\int_{0}^{\infty} x^{y-1} \exp (-x) d x
$$

and $\mathrm{K}_{\theta k}$ is the order-modified Bessel function $\theta_{k}$; j-bessel,

$$
(h)=C_{0}+C_{1}\left[1-\frac{2^{\theta_{d}} \Gamma\left(\theta_{d}+1\right)}{\left(\frac{\Omega_{\theta_{d}} h}{a}\right)^{\theta_{d}}} J_{\theta_{d}}\left(\frac{\Omega_{\theta_{d}} h}{a}\right)\right]
$$

for all h, where $C_{0}+C_{1} \geq 0, a \geq 0, \theta_{d} \geq 0, \Omega_{\theta_{d}}$, must satisfy, $B=a, B>0, \gamma(B)=C_{0}+C_{1}, \gamma^{\prime}(B)<0$ and $J_{\theta_{d}}$ in the jbessel function; Stable,

$$
\gamma(h)=C_{0}+C_{1}\left[1-e^{\left(-3\left(\frac{h}{a}\right)^{\theta_{e}}\right)}\right]
$$

for all h, where $C_{0}+C_{1}$ e $0 \leq \theta_{e} \leq 2$; estimated according to Johnson et al. [17] in ArcGis 9.2 software.

In order to verify the existence of spatial dependence, the Spatial Dependency Index (SDI), which represents a ratio of spatial dependence, quantified by the semivariogram model, is estimated to contribute to the variability of the data, $S D I=\frac{C_{1}}{C_{0}+C_{1}}$, being classified as strong (SDI> 75\%), medium $(25<\mathrm{SDI} \leq 75 \%)$ and low (SDI $\leq 25 \%$ ) [18]. Based on the presence of spatial dependence between the data, OK inferences were performed, estimating values at unmeasured locations.

For the choice of the semivariogram model the cross-validation technique was used according to Webster and Oliver [19], the weighted sum of the linear regression indicators (intersection "b", angular coefficient "a" and coefficient of determination " $\left.R^{2 "}\right)$, mean of errors $(\bar{E})$, standard deviation of errors $(D P E)$, mean of absolute errors $(\overline{E A})$, root mean square of errors (RQME) and the mean square root of errors standardized (RQMEP) according Pasini et al. [16] .

The inverse of the distance weighted (IDW) is a univariate deterministic interpolator of weighted averages, $\hat{Z}_{i}=\frac{\sum_{i=1}^{n}\left(\frac{1}{d_{i}^{\lambda}} \times Z_{i}\right)}{\sum_{i=1}^{n}\left(\frac{1}{d_{i}^{\lambda}}\right)}$, on what $\hat{Z}_{i}$ is the interpolated value, $Z_{i}$ is the value sampled and $d_{i}$ is the Euclidean distance between the sampled and the estimated point, $n$ number of neighboring points used in the interpolation and $\lambda$ is the weighting exponent of the Euclidean distance, which is applied to the weights 2,3 , 4,5 and 6.

For the selection of the best weighting weight, cross-validation was applied through linear regression $(a$, b, $\left.R^{2}\right), \bar{E}=\frac{\sum_{i=1}^{n}\left[Z\left(s_{i}\right)-z\left(s_{i}\right)\right]}{n}, D P E=\sqrt{\frac{\sum_{i=1}^{n}\left\{\left[\hat{Z}\left(s_{i}\right)-z\left(s_{i}\right)\right]-\bar{E}\right\}^{2}}{n-1}}, \overline{E A}=\frac{\sum_{i=1}^{n}\left|\left[\hat{Z}\left(s_{i}\right)-z\left(s_{i}\right)\right]\right|}{n}$ e $R Q M E=\sqrt{\frac{\sum_{i=1}^{n}\left[\hat{Z}\left(s_{i}\right)-z\left(s_{i}\right)\right]^{2}}{n}}$.

From the estimated cross-validation indicators, scores from 1 to 5 were assigned, according to the selection criterion of each indicator: for the estimates of $b, R^{2}$ the value closest or equal to 1 was assigned to note 5 and to the farthest value of 1 was assigned to note 1 , respectively; for the estimates $a, b, \bar{E}, D P E$, $C V E, \overline{E A}$ and $R Q M E$ the value closest to or equal to 0 was assigned to note 5 and to the farthest value of 0 was assigned to note 1, respectively. After the assignment of the notes, the sum of these were carried out within each weight and situation evaluated adopting the criterion of choice of the model with the highest sum of the notes. 
For the choice of the best interpolator between ordinary kriging and the inverse of the distance weighted, the cross-validation between the best theoretical model of semivariogram and the best weighting weight was applied through the indicators $a, b, R^{2}, \bar{E}, D P E, \overline{E A}$ e $R Q M E$. From the estimated cross-validation indicators, scores from 1 to 2 were assigned, according to the selection criterion of each indicator: for the estimates of $b, R^{2}$ the value closest or equal to 1 was assigned to note 2 and to the farthest value of 1 was assigned to note 1, respectively; for the estimates a, $b, \bar{E}, D P E, C V E, \overline{E A}$ e $R Q M E$ the value closest to or equal to 0 was assigned to note 2 and to the farthest value of 0 was assigned to note 1 , respectively. After the assignment of the notes, the sum of these was performed within each interpolator adopting the criterion of choice of the method with the highest sum of the notes. As a complementary evaluation between the interpolators, the estimation maps for each crop and evaluation were generated.

\section{RESULTS AND DISCUSSION}

A total of 8414 adults of Tibraca limbativentris were collected and identified, corresponding to an average of 6.69 adults $\mathrm{m}^{-2}$ per tillage and by evaluation. The asymmetry values showed that for most evaluations in the fields, the data presented a positive asymmetry (Table 1), results influenced by the greater amount of low values or zeros. This behavior of the distribution of the data is related to the $T$. limbativentris dispersion patterns and its concentration in areas near the borders of the field. According to Yamamoto and Landim [20], when the distribution has positive asymmetry, data transformation is necessary to avoid the influence of few high values in the estimation of neighborhood points characterized by low values. However, for data with normal distribution or with negative asymmetry there is no need for data transformation. For evaluations where there was a need for transformation, all presented significance in the Shapiro-Wilk test after the test (Table 2).

In both areas and evaluations, the theoretical models indicated a spatial dependence greater than $75 \%$. Such values suggest a strong contribution from space on data variability [18]. In this way, inferences can be made from the ordinary kriging for the theoretical models of semivariograms in the evaluations and fields. From the selection criteria, 9 models of semivariograms were selected for the 14 evaluations (Table 3). It was also found that the cross-validation indicators differed in relation to their estimated values for the same model tested, which generated differences in the scores for selection. This highlights the importance of using a greater number of indicators for decision making [16]. 
Table 2. Descriptive statistics of the number of adults of Tibraca limbativentris (Hemiptera: Pentatomidae) per $\mathrm{m}^{2}$ sampled in the phenological stages of irrigated rice fields. Santa Maria, Rio Grande do Sul, Brazil, 2012/13 harvest.

\begin{tabular}{|c|c|c|c|c|c|c|c|c|c|c|c|c|c|c|}
\hline \multirow[b]{2}{*}{ Descriptive Statistics } & \multicolumn{7}{|c|}{ Phenological stages } & \multicolumn{7}{|c|}{ Phenological stages } \\
\hline & V3 & V6 & V9(R0) & $\mathrm{R} 2$ & $\mathrm{R} 4$ & R6 & $\mathrm{R} 9$ & V3 & V6 & V9(R0) & $\mathrm{R} 2$ & R4 & R6 & $\mathrm{R9}$ \\
\hline & \multicolumn{7}{|c|}{----------- Field 01 ----------- } & \multicolumn{7}{|c|}{-------- Field 02 ---------- } \\
\hline Average & 0.41 & 1.62 & 4.28 & 12.10 & 13.85 & 16.31 & 12.59 & 0.34 & 1.10 & 3.39 & 3.75 & 6.62 & 6.99 & 7.56 \\
\hline Standard deviation & 0.64 & 1.63 & 3.19 & 4.94 & 3.52 & 4.32 & 3.31 & 0.67 & 1.19 & 3.11 & 3.99 & 4.21 & 4.55 & 4.95 \\
\hline Coefficient variation & 1.55 & 1.01 & 0.74 & 0.41 & 0.25 & 0.27 & 0.26 & 1.97 & 1.08 & 0.91 & 1.06 & 0.63 & 0.65 & 0.66 \\
\hline Minimum & 0 & 0 & 0 & 2 & 7 & 8 & 6 & 0 & 0 & 0 & 1 & 2 & 2 & 2 \\
\hline Maximum & 2 & 5 & 12 & 21 & 19 & 26 & 19 & 3 & 6 & 13 & 16 & 19 & 20 & 21 \\
\hline Sum & 16 & 63 & 167 & 472 & 540 & 636 & 491 & 65 & 213 & 651 & 1032 & 1272 & 1343 & 1453 \\
\hline Assimmetry & 1.32 & 0.82 & 0.42 & -0.44 & -0.54 & 0.14 & 0.28 & 2.16 & 1.08 & 1.08 & 1.18 & 1.17 & 1.27 & 1.35 \\
\hline Kurtosis & 0.69 & -0.55 & -0.80 & -0.86 & -0.66 & -0.63 & -0.71 & 4.53 & 0.96 & 0.29 & 0.08 & 0.11 & 0.43 & 0.59 \\
\hline$p$-value SW test & ns & ns & ns & ns & ns & $0.55^{*}$ & $0.19^{*}$ & ns & ns & ns & ns & ns & ns & ns \\
\hline$\lambda($ Box-Cox $)$ & -1.74 & 0 & 0.42 & - & - & - & - & -2.5 & 0 & 0.58 & 0.47 & 0.68 & 1.03 & 0.98 \\
\hline$p$-value SW test & $0.06^{*}$ & $0.07^{*}$ & $0.09^{*}$ & - & - & - & - & $0.06^{*}$ & $0.06^{*}$ & $0.07^{*}$ & $0.06^{*}$ & $0.07^{*}$ & $0.10^{*}$ & $0.06^{*}$ \\
\hline
\end{tabular}

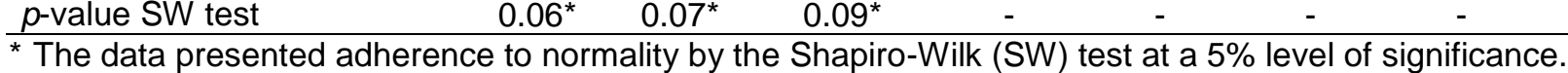


Table 3. Parameters of the theoretical semivariogram models selected from the sum criterion of the cross-validation indicators, for the fields and crop phenology.

\begin{tabular}{|c|c|c|c|c|c|c|c|c|c|c|c|c|c|c|}
\hline & \multicolumn{5}{|c|}{ Selection Model ${ }^{2}$} & \multicolumn{9}{|c|}{ Cross validation $^{3}$} \\
\hline & Models ${ }^{1}$ & $\mathrm{C}_{0}$ & $\mathrm{C}_{1}$ & a & $I D E$ & a & b & $\mathrm{R}^{2}$ & $\bar{E}$ & $\overline{E A}$ & $D P E$ & $R Q M E$ & RQMEP & $\Sigma$ \\
\hline & & & & & & & & eld 01 -----. & & ------- & & & & \\
\hline V3 & JB & 0.052 & 0.407 & 82.9 & 89 & $0.740(9)$ & $0.104(9)$ & $0.736(10)$ & $-0.003(9)$ & $0.235(9)$ & $0.327(10)$ & $0.310(11)$ & $0.916(10)$ & 77 \\
\hline V6 & JB & 0.362 & 1.912 & 151.2 & 84 & $0.552(11)$ & $0.722(11)$ & $0.530(11)$ & $-0.002(8)$ & $0.739(11)$ & $1.119(11)$ & $1.105(11)$ & $0.992(9)$ & 83 \\
\hline V9 & $\mathrm{C}$ & 0 & 9.069 & 40.3 & 100 & $0.671(7)^{\prime}$ & $1.479(7)^{\prime}$ & $0.781(11)$ & $0.072(4)$ & $1.455(11)$ & $1.801(11)$ & $1.798(11)$ & $0.757(3)$ & 65 \\
\hline $\mathrm{R} 2$ & Es & 3.899 & 21.248 & 60.1 & 84 & $0.703(8)$ & $3.786(8)$ & $0.675(8)$ & $0.193(7)$ & $2.108(7)$ & $2.817(9)$ & $2.884(5)$ & $1.023(11)$ & 63 \\
\hline R4 & $\mathrm{KB}$ & 0 & 10.051 & 36.5 & 100 & $0.565(10)$ & $6.027(10)$ & $0.530(10)$ & $0.000(11)$ & $1.887(9)$ & $2.418(11)$ & $2.387(11)$ & $0.962(9)$ & 81 \\
\hline R6 & C & 2.164 & 25.083 & 119.0 & 92 & $0.532(8)$ & $7.719(7)$ & $0.489(11)$ & $0.086(3)$ & $2.445(11)$ & $3.101(11)$ & $3.579(9)$ & $1.124(9)$ & 69 \\
\hline & & & & & & & & & & & & & & \\
\hline V3 & $\mathrm{RQ}$ & 0 & 0.437 & 98.1 & 100 & $0.668(9)$ & $0.100(9)$ & $0.654(10)$ & $-0.013(7)$ & $0.217(11)$ & $0.392(11)$ & $0.391(11)$ & $0.972(11)$ & 79 \\
\hline V6 & E & 0 & 1.480 & 130.3 & 100 & $0.742(10)$ & $0.267(9)$ & $0.709(11)$ & $-0.016(9)$ & $0.440(9)$ & $0.642(11)$ & $0.641(11)$ & $1.183(3)$ & 73 \\
\hline V9 & Es & 0 & 2.615 & 40.8 & 100 & $0.928(11)$ & $0.222(10)$ & $0.895(11)$ & $-0.021(6)$ & $0.715(11)$ & $1.014(7)$ & $1.012(7)$ & $1.162(8)$ & 71 \\
\hline $\mathrm{R} 2$ & C & 0 & 5.745 & 56.8 & 100 & $0.958(8)$ & $0.219(7)$ & $0.954(11)$ & $-0.006(6)$ & $0.666(11)$ & $0.853(11)$ & $0.851(11)$ & $0.605(8)$ & 73 \\
\hline R4 & G & 0 & 4.262 & 41.7 & 100 & $0.966(9)$ & $0.218(9)$ & $0.950(11)$ & $-0.008(9)$ & $0.805(8)$ & $1.037(11)$ & $1.034(11)$ & $0.988(11)$ & 79 \\
\hline R6 & $\mathrm{G}$ & 0 & 4.064 & 42.1 & 100 & $0.973(11)$ & $0.160(11)$ & $0.943(11)$ & $-0.008(7)$ & $0.873(10)$ & $1.113(11)$ & $1.110(11)$ & $1.001(11)$ & 83 \\
\hline $\mathrm{R} 9$ & $\mathrm{P}$ & 0 & 13.857 & 126.7 & 100 & $0.928(2)$ & $0.542(3)$ & $0.939(11)$ & $-0.003(9)$ & $0.910(11)$ & $1.225(11)$ & $1.221(11)$ & $0.674(4)$ & 63 \\
\hline
\end{tabular}

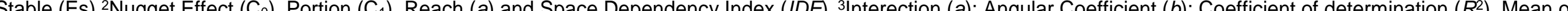

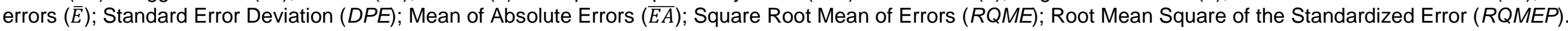


In field 01, the J-Bessel model presented the highest sum of the scores between the models in the V3 and V6 stages; the Circular model in the V9 and R6; the Stable model in the R2; the K-Bessel model in the R4 and the Tetraspheric model in the R9 (Table 3). In field 02, the Rational Quadratic model in the V3 assessment; the Spherical model in the V6; the Stable model in the V9; the Circular model in the R2; the Gaussian model in the R4 and R6 evaluations; and the Pentaspheric model in the R9 stage (Table 3). Such results differing from the model used by Grego and coauthors [21] in Pseudaletia sequax (Lepidoptera: Noctuidae), Dinardo-Miranda and coauthors [22] in Mahanarva fimbriolata (Hemiptera: Cercopidae), Dal Prá and coauthors [23] in Diloboderus abderus (Coleoptera: Melolonthidae) and Dinardo-Miranda and coauthors [22] in Cotesia flavipes (Hymenoptera: Braconidae).

Of the models with greater sum, there was effect nugget only in the field 01 (V3, V6, R2, R6 and R9 stages), however, this did not affect the spatial dependency index of these assessments. The range values were higher than the sampling mesh, indicating that the grid used was adequate. The nugget effect indicates the part of the variance that cannot be explained by the spatial dependence. The range values were higher than those chosen for sampling, indicating the adequacy of the sampling grid employed.

The weights were selected according to the criterion of choice (Table 4). In field 01, the sixth weighting was selected in the stages $\mathrm{V} 3, \mathrm{~V} 9, \mathrm{R} 2, \mathrm{R} 4, \mathrm{R} 6$ and $\mathrm{R} 9$ and the third weighting in the stage V9. In field 02 the third weighting was selected in evaluations $\mathrm{V} 3$ and $\mathrm{V} 6$, the sixth in $\mathrm{V} 9, \mathrm{R} 4, \mathrm{R} 6$ and $\mathrm{R} 9$ stages, and the fourth weight in the R2 stage. For most evaluations, higher value weights were selected, indicating that for $T$. limbativentris estimates the lower the influence of more distant points. However, in the choice of weights there is no direct or inverse relation to the descriptive statistics.

For all evaluations, the ordinary kriging interpolator was superior to the inverse of distance weighted (Table 5), agreeing with Mello and coauthors [7], Soares and coauthors [11], Silva and coauthors [6], Silva and coauthors [24]. According to Soares and coauthors [11] the superiority of the ordinary kriging interpolator is attributed to the non-bias of the estimator and the minimum variance of the estimates being considered an optimal interpolator. The values obtained from the cross-validation indicators show that both methods of interpolation in their estimates were biased, with intersection values higher than zero and angular coefficient lower than one (Table 5). This result indicates that there was overestimation for low values and underestimation of the high values, agreeing with Yamamoto and Landim [27]. However, from the mean of the errors, it has been found that this underestimation or overestimation is less than an adult individual of $T$. limbativentris per $\mathrm{m}^{2}$, and is not very representative.

There was a direct relationship between the mean values of absolute errors and the increase in the population density of $T$. limbativentris (Table 1), with a higher value for R6 stage (Table 5). However, the values of the standard deviation of the errors and mean square root of the errors indicate that there is a smaller variation of these with respect to the mean for the ordinary kriging interpolator, which stands out its greater accuracy with respect to the inverse of distance weighted interpolator. 
Table 4. Estimates of cross validation and assigned scores (in parentheses) from the inverse of distance weighted (IDW) interpolator of different weights in the evaluations of fields 01 and 02 .

\begin{tabular}{|c|c|c|c|c|c|c|c|c|c|c|}
\hline \multirow{3}{*}{ Indicator $^{1}$} & \multirow{2}{*}{\multicolumn{5}{|c|}{$\begin{array}{c}\text { Field } 01 \\
\text { Weighting }\end{array}$}} & \multicolumn{5}{|c|}{ Field 02} \\
\hline & \multicolumn{3}{|r|}{ Weighting } & & & \multicolumn{5}{|c|}{ Weighting } \\
\hline & 2 & 3 & 4 & 5 & 6 & 2 & 3 & 4 & 5 & 6 \\
\hline$a$ & $0.320(1)$ & $0.402(2)$ & $0.465(3)$ & $0.508(4)$ & $0.537(5)$ & $0.489(1)$ & $0.527(2)$ & $0.548(3)$ & $0.557(4)$ & $0.561(5)$ \\
\hline$b$ & $0.259(1)$ & $0.231(2)$ & $0.210(3)$ & $0.196(4)$ & $0.186(5)$ & $0.151(1)$ & $0.145(2)$ & $0.141(3)$ & $0.140(5)$ & $0.140(5)$ \\
\hline$R^{2}$ & $0.539(1)$ & $0.636(2)$ & $0.679(3)$ & $0.692(4)$ & $0.693(5)$ & $0.578(1)$ & $0.572(2)$ & $0.551(3)$ & $0.528(4)$ & $0.506(5)$ \\
\hline $\bar{E}$ & $-0.020(1)$ & $-0.014(2)$ & $-0.009(3)$ & $-0.006(4)$ & $-0.003(5)$ & $-0.022(1)$ & $-0.011(3)$ & $-0.012(2)$ & $-0.010(4)$ & $-0.009(5)$ \\
\hline$\overline{E A}$ & $0.352(1)$ & $0.311(2)$ & $0.283(3)$ & $0.266(4)$ & $0.258(5)$ & $0.246(4)$ & $0.245(5)$ & $0.248(3)$ & $0.252(2)$ & $0.257(1)$ \\
\hline$D P E$ & $0.473(1)$ & $0.427(2)$ & $0.398(3)$ & $0.381(4)$ & $0.373(5)$ & $0.440(4)$ & $0.438(5)$ & $0.447(3)$ & $0.459(2)$ & $0.472(1)$ \\
\hline$R Q M E$ & $0.467(1)$ & $0.422(2)$ & $0.392(3)$ & $0.375(4)$ & $0.366(5)$ & $0.440(4)$ & $0.437(5)$ & $0.446(3)$ & $0.458(2)$ & $0.471(1)$ \\
\hline$\Sigma$ & 7 & 14 & 21 & 28 & 35 & 16 & 24 & 21 & 23 & 23 \\
\hline$a$ & $0.383(1)$ & $0.410(2)$ & $0.430(3)$ & $0.444(4)$ & $0.452(5)$ & $0.607(1)$ & $0.642(2)$ & $0.664(3)$ & $0.676(4)$ & $0.682(5)$ \\
\hline$b$ & $0.955(1)$ & $0.926(2)$ & $0.905(3)$ & $0.893(4)$ & $0.886(5)$ & $0.392(1)$ & $0.363(2)$ & $0.346(3)$ & $0.335(4)$ & $0.330(5)$ \\
\hline$R^{2}$ & $0.414(5)$ & $0.403(4)$ & $0.389(3)$ & $0.374(2)$ & $0.360(1)$ & $0.691(5)$ & $0.690(4)$ & $0.681(3)$ & $0.669(2)$ & $0.657(1)$ \\
\hline $\bar{E}$ & $-0.042(1)$ & $-0.027(2)$ & $-0.015(3)$ & $-0.006(4)$ & $0.000(5)$ & $-0.045(1)$ & $-0.034(2)$ & $-0.027(3)$ & $-0.024(4)$ & $-0.022(5)$ \\
\hline$\overline{E A}$ & $0.906(1)$ & $0.882(5)$ & $0.887(4)$ & $0.894(3)$ & $0.902(2)$ & $0.470(2)$ & $0.463(5)$ & $0.464(4)$ & $0.468(3)$ & $0.473(1)$ \\
\hline$D P E$ & $1.252(5)$ & $1.262(4)$ & $1.281(3)$ & $1.305(2)$ & $1.330(1)$ & $0.680(4)$ & $0.674(5)$ & $0.681(3)$ & $0.693(2)$ & $0.705(1)$ \\
\hline$R Q M E$ & $1.236(5)$ & $1.243(4)$ & $1.262(3)$ & $1.285(2)$ & $1.310(1)$ & $0.680(3)$ & $0.673(5)$ & $0.679(4)$ & $0.691(2)$ & $0.704(1)$ \\
\hline$\Sigma$ & 20 & 23 & 22 & 21 & 20 & 17 & 25 & 23 & 21 & 19 \\
\hline$a$ & $0.386(1)$ & $0.451(2)$ & $0.496(3)$ & $0.524(4)$ & $0.541(5)$ & $0.803(1)$ & $0.831(2)$ & $0.848(3)$ & $0.857(4)$ & $0.863(5)$ \\
\hline$b$ & $2.721(1)$ & $2.477(2)$ & $2.309(3)$ & $2.205(4)$ & $2.146(5)$ & $0.598(1)$ & $0.534(2)$ & $0.495(3)$ & $0.471(4)$ & $0.457(5)$ \\
\hline$R^{2}$ & $0.531(1)$ & $0.592(2)$ & $0.616(3)$ & $0.622(5)$ & $0.621(4)$ & $0.874(5)$ & $0.885(4)$ & $0.890(3)$ & $0.893(2)$ & $0.895(1)$ \\
\hline $\bar{E}$ & $0.093(5)$ & $0.127(4)$ & $0.151(3)$ & $0.168(2)$ & $0.179(1)$ & $-0.072(1)$ & $-0.040(2)$ & $-0.022(3)$ & $-0.012(4)$ & $-0.008(5)$ \\
\hline$\overline{E A}$ & $1.733(1)$ & $1.615(2)$ & $1.565(3)$ & $1.554(5)$ & $1.561(4)$ & $0.839(1)$ & $0.796(2)$ & $0.773(3)$ & $0.763(4)$ & $0.756(5)$ \\
\hline$D P E$ & $2.272(1)$ & $2.117(2)$ & $2.034(3)$ & $1.999(4)$ & $1.989(5)$ & $1.129(1)$ & $1.072(2)$ & $1.041(3)$ & 1.024(4) & $1.015(5)$ \\
\hline$R Q M E$ & $2.244(1)$ & $2.093(2)$ & $2.014(3)$ & $1.980(4)$ & $1.971(5)$ & $1.128(1)$ & $1.069(2)$ & $1.038(3)$ & $1.022(4)$ & $1.012(5)$ \\
\hline$\Sigma$ & 11 & 16 & 21 & 28 & 29 & 11 & 16 & 21 & 26 & 31 \\
\hline$a$ & $0.470(1)$ & $0.529(2)$ & $0.576(3)$ & $0.609(4)$ & & & & $0.910(3)$ & $0.919(4)$ & $0.924(5)$ \\
\hline$b$ & $6.697(1)$ & $5.986(2)$ & $5.447(3)$ & $5.063(4)$ & 794(5) & $0.642(1)$ & $0.548(2)$ & $0.491(3)$ & $0.458(4)$ & $0.439(5)$ \\
\hline$R^{2}$ & $0.581(1)$ & $0.627(2)$ & $0.651(3)$ & $0.662(4)$ & $0.666(5)$ & $0.940(1)$ & $0.946(2)$ & $0.948(3)$ & $0.948(3)$ & $0.947(5)$ \\
\hline $\bar{E}$ & $0.278(5)$ & $0.291(4)$ & $0.311(3)$ & $0.332(2)$ & $0.349(1)$ & $-0.066(1)$ & $-0.019(3)$ & $0.009(5)$ & $0.024(4)$ & $0.032(2)$ \\
\hline$\overline{E A}$ & $2.438(1)$ & $2.263(2)$ & $2.160(3)$ & 2.158(2) & $2.155(1)$ & $0.794(1)$ & $0.742(2)$ & $0.706(5)$ & $0.707(3)$ & $0.707(3)$ \\
\hline$D P E$ & $3.276(1)$ & $3.074(2)$ & $2.950(3)$ & $2.887(4)$ & $2.858(5)$ & $1.019(1)$ & $0.953(2)$ & $0.907(5)$ & $0.920(4)$ & $0.922(3)$ \\
\hline$R Q M E$ & $3.245(1)$ & $3.048(2)$ & 2.928(3) & $2.868(4)$ & $2.843(5)$ & $1.019(1)$ & $0.951(2)$ & $0.904(5)$ & $0.918(4)$ & $0.920(3)$ \\
\hline$\Sigma$ & 7 & 16 & 21 & 24 & 27 & 7 & 15 & 29 & 26 & 26 \\
\hline$a$ & $0.373(1)$ & $0.423(2)$ & $0.461(3)$ & $0.488(4)$ & $0.506(5)$ & $0.833(1)$ & $0.866(2)$ & $0.886(3)$ & $0.897(4)$ & $0.903(5)$ \\
\hline$b$ & $8.658(1)$ & 7.997(2) & $7.512(3)$ & $7.182(4)$ & $6.966(5)$ & $1.025(1)$ & $0.864(2)$ & $0.765(3)$ & $0.706(4)$ & $0.671(5)$ \\
\hline$R^{2}$ & $0.439(1)$ & $0.466(2)$ & $0.481(3)$ & $0.488(4)$ & $0.491(5)$ & $0.916(1)$ & $0.925(2)$ & $0.929(3)$ & $0.931(4)$ & $0.932(5)$ \\
\hline $\bar{E}$ & $-0.018(4)$ & $0.013(5)$ & $0.055(3)$ & $0.096(2)$ & $0.131(1)$ & $-0.080(1)$ & $-0.023(3)$ & $0.009(5)$ & $0.023(3)$ & $0.030(2)$ \\
\hline$\overline{E A}$ & $2.171(1)$ & $2.093(2)$ & $2.023(3)$ & $1.966(4)$ & $1.924(5)$ & $0.982(1)$ & $0.903(2)$ & $0.862(3)$ & $0.842(4)$ & $0.834(5)$ \\
\hline$D P E$ & 2.661(1) & $2.582(2)$ & $2.538(3)$ & $2.519(4)$ & $2.513(5)$ & $1.296(1)$ & $1.200(2)$ & $1.154(3)$ & $1.134(4)$ & $1.124(5)$ \\
\hline$R Q M E$ & 2.639(1) & $2.549(2)$ & $2.505(3)$ & $2.487(4)$ & $2.483(5)$ & $1.295(1)$ & 1.197(2) & $1.151(3)$ & $1.131(4)$ & 1.121(5) \\
\hline$\Sigma$ & 10 & 17 & 21 & 26 & 31 & 7 & 15 & 23 & 27 & 32 \\
\hline$a$ & $0.429(1)$ & $0.444(2)$ & $0.454(3)$ & $0.460(4)$ & $0.463(5)$ & & $0.862(2)$ & $0.881(3)$ & $0.892(4)$ & $0.898(5)$ \\
\hline$b$ & 9.390(1) & $9.132(2)$ & $8.955(3)$ & $8.844(4)$ & $8.778(5)$ & $1.091(1)$ & $0.923(2)$ & $0.820(3)$ & $0.757(4)$ & $0.719(5)$ \\
\hline$R^{2}$ & $0.470(5)$ & $0.462(4)$ & $0.454(3)$ & $0.447(2)$ & $0.440(1)$ & $0.914(1)$ & $0.922(2)$ & $0.926(3)$ & $0.928(4)$ & $0.929(5)$ \\
\hline $\bar{E}$ & $0.086(1)$ & $0.072(2)$ & $0.056(3)$ & $0.040(4)$ & $0.027(5)$ & $-0.096(1)$ & $-0.044(2)$ & $-0.015(3)$ & $0.000(5)$ & $0.008(4)$ \\
\hline$\overline{E A}$ & $2.543(1)$ & $2.553(2)$ & $2.561(3)$ & $2.567(4)$ & $2.573(5)$ & $1.041(1)$ & $0.973(2)$ & $0.942(3)$ & $0.931(4)$ & $0.923(5)$ \\
\hline$D P E$ & $3.157(5)$ & $3.173(4)$ & $3.195(3)$ & $3.217(2)$ & $3.240(1)$ & $1.396(1)$ & $1.303(2)$ & $1.257(3)$ & $1.234(4)$ & $1.224(5)$ \\
\hline$R Q M E$ & 3.386(5) & $3.483(4)$ & $3.564(3)$ & $3.620(2)$ & $3.656(1)$ & 1.396(1) & $1.300(2)$ & $1.254(3)$ & $1.231(4)$ & $1.220(5)$ \\
\hline$\Sigma$ & 19 & 20 & 21 & 22 & 23 & 7 & 14 & 21 & 29 & 34 \\
\hline$a$ & $0.316(1)$ & $0.379(2)$ & $0.426(3)$ & & $0.481(5)$ & & & $0.872(3)$ & $0.884(4)$ & $0.891(5)$ \\
\hline$b$ & 8.632(1) & 7.817(2) & $7.220(3)$ & $6.804(4)$ & $6.517(5)$ & $1.264(1)$ & $1.061(2)$ & $0.935(3)$ & $0.863(4)$ & $0.821(5)$ \\
\hline$R^{2}$ & $0.438(1)$ & $0.485(2)$ & $0.503(3)$ & $0.509(4)$ & $0.510(5)$ & $0.910(1)$ & $0.920(2)$ & $0.924(3)$ & $0.926(5)$ & $0.926(5)$ \\
\hline $\bar{E}$ & $0.022(1)$ & $0.001(5)$ & $-0.012(4)$ & $-0.016(2)$ & $-0.013(3)$ & $-0.119(1)$ & $-0.065(2)$ & $-0.033(3)$ & $-0.017(4)$ & $-0.007(5)$ \\
\hline$\overline{E A}$ & $2.049(1)$ & 1.923(2) & 1.868(3) & $1.838(4)$ & $1.820(5)$ & 1.132(1) & $1.051(2)$ & $1.003(3)$ & $0.985(4)$ & $0.976(5)$ \\
\hline$D P E$ & 2.558(1) & $2.432(2)$ & $2.364(3)$ & $2.334(4)$ & $2.324(5)$ & $1.560(1)$ & $1.448(2)$ & 1.393(3) & $1.368(4)$ & $1.358(5)$ \\
\hline$R Q M E$ & $2.540(1)$ & $2.404(2)$ & 2.334(3) & 2.303(4) & $2.293(5)$ & $1.560(1)$ & $1.446(2)$ & $1.389(3)$ & $1.364(4)$ & $1.355(5)$ \\
\hline$\Sigma$ & 7 & 17 & 22 & 26 & 33 & 7 & 14 & 21 & 29 & 35 \\
\hline
\end{tabular}

1'Interection (a); Angular Coefficient (b); Coefficient of determination $\left(R^{2}\right)$, Mean of errors $(\bar{E})$; Standard Error Deviation $(D P E)$; Mean of Absolute Errors $(\overline{E A})$; Square Root Mean of Errors $(R Q M E)$; Root Mean Square of the Standardized Error $(R Q M E P)$. 
Table 5. Estimates of cross-validation and scores awarded (in parentheses) from the best semivariogram model in ordinary kriging (OK) and the best weight for the inverse of distance weighted (IDW) in the assessments of fields 01 and 02.

\begin{tabular}{|c|c|c|c|c|}
\hline \multirow{2}{*}{ Indicator } & \multicolumn{2}{|c|}{ Field 01} & \multicolumn{2}{|c|}{ Field 02} \\
\hline & OK & IDW & OK & IDW \\
\hline & & & & \\
\hline$a$ & $0.740(2)$ & $0.537(1)$ & $0.668(2)$ & $0.527(1)$ \\
\hline$b$ & $0.104(2)$ & $0.186(1)$ & $0.100(2)$ & $0.145(1)$ \\
\hline$R^{2}$ & $0.736(2)$ & 0.693(1) & $0.654(2)$ & $0.572(1)$ \\
\hline $\bar{E}$ & $-0.003(2)$ & $-0.003(2)$ & $-0.013(1)$ & $-0.011(2)$ \\
\hline$\overline{E A}$ & $0.235(2)$ & $0.258(1)$ & $0.217(2)$ & $0.245(1)$ \\
\hline$D P E$ & $0.327(2)$ & $0.373(1)$ & $0.392(2)$ & $0.438(1)$ \\
\hline$R Q M E$ & $0.310(2)$ & $0.366(1)$ & $0.391(2)$ & $0.437(1)$ \\
\hline$\Sigma$ & 14 & 8 & 13 & 8 \\
\hline$a$ & $0.552(2)$ & $0.410(1)$ & $0.742(2)$ & $0.642(1)$ \\
\hline$b$ & $0.722(2)$ & $0.926(1)$ & $0.267(2)$ & $0.363(1)$ \\
\hline$R^{2}$ & $0.530(2)$ & $0.403(1)$ & $0.709(2)$ & $0.690(1)$ \\
\hline $\bar{E}$ & $-0.002(2)$ & $-0.027(1)$ & $-0.016(2)$ & $-0.034(1)$ \\
\hline$\overline{E A}$ & $0.739(2)$ & $0.882(1)$ & $0.440(2)$ & $0.463(1)$ \\
\hline$D P E$ & $1.119(2)$ & $1.262(1)$ & $0.642(2)$ & $0.674(1)$ \\
\hline$R Q M E$ & $1.105(2)$ & $1.243(1)$ & $0.641(2)$ & $0.673(1)$ \\
\hline$\Sigma$ & 14 & 7 & 14 & 7 \\
\hline$a$ & $0.671(2)$ & $0.654(1)$ & $0.928(2)$ & $0.857(1)$ \\
\hline$b$ & $1.479(2)$ & $2.216(1)$ & $0.222(2)$ & $0.471(1)$ \\
\hline$R^{2}$ & $0.781(2)$ & $0.704(1)$ & $0.895(2)$ & $0.893(1)$ \\
\hline $\bar{E}$ & $0.072(2)$ & $-0.127(1)$ & $-0.021(1)$ & $-0.012(2)$ \\
\hline$\overline{E A}$ & $1.455(1)$ & $1.329(2)$ & $0.715(2)$ & $0.763(1)$ \\
\hline$D P E$ & 1.801(1) & $1.629(2)$ & $1.014(2)$ & $1.024(1)$ \\
\hline$R Q M E$ & $1.798(1)$ & $1.570(2)$ & $1.012(2)$ & $1.022(1)$ \\
\hline$\Sigma$ & 11 & 10 & 13 & 8 \\
\hline$a$ & $0.681(2)$ & $0.633(1)$ & $0.958(2)$ & $0.910(1)$ \\
\hline$b$ & $4.068(2)$ & 4.794(1) & $0.219(2)$ & $0.491(1)$ \\
\hline$R^{2}$ & $0.678(2)$ & $0.666(1)$ & $0.954(2)$ & $0.948(1)$ \\
\hline $\bar{E}$ & $0.212(2)$ & $0.349(1)$ & $-0.006(2)$ & $0.009(1)$ \\
\hline$\overline{E A}$ & $2.098(2)$ & $2.155(1)$ & $0.666(2)$ & $0.706(1)$ \\
\hline$D P E$ & $2.800(2)$ & $2.858(1)$ & $0.853(2)$ & $0.907(1)$ \\
\hline$R Q M E$ & 2.824(2) & $2.843(1)$ & $0.851(2)$ & $0.904(1)$ \\
\hline$\Sigma$ & 14 & 7 & 14 & 7 \\
\hline$a$ & $0.565(2)$ & $0.506(1)$ & $0.966(2)$ & $0.903(1)$ \\
\hline$b$ & $6.027(2)$ & $6.966(1)$ & $0.218(2)$ & $0.671(1)$ \\
\hline$R^{2}$ & $0.530(2)$ & $0.491(1)$ & $0.950(2)$ & $0.932(1)$ \\
\hline $\bar{E}$ & $0.000(2)$ & $0.131(1)$ & $-0.008(2)$ & $0.030(1)$ \\
\hline$\overline{E A}$ & 1.887(2) & 1.924(1) & $0.805(2)$ & $0.834(1)$ \\
\hline$D P E$ & $2.418(2)$ & $2.513(1)$ & $1.037(2)$ & $1.124(1)$ \\
\hline$R Q M E$ & 2.387(2) & $2.483(1)$ & $1.034(2)$ & 1.121(1) \\
\hline$\Sigma$ & 14 & 7 & 14 & 7 \\
\hline$a$ & $0.532(2)$ & $0.463(1)$ & $0.973(2)$ & $0.898(1)$ \\
\hline$b$ & $7.719(2)$ & $8.778(1)$ & $0.160(2)$ & $0.719(1)$ \\
\hline$R^{2}$ & $0.489(2)$ & $0.440(1)$ & $0.943(2)$ & $0.929(1)$ \\
\hline $\bar{E}$ & $0.086(1)$ & $0.027(2)$ & $-0.008(2)$ & $0.008(2)$ \\
\hline$\overline{E A}$ & $2.445(2)$ & $2.573(1)$ & $0.873(2)$ & $0.923(1)$ \\
\hline$D P E$ & $3.101(2)$ & $3.240(1)$ & $1.113(2)$ & $1.224(1)$ \\
\hline$R Q M E$ & $3.579(2)$ & $3.656(1)$ & $1.110(2)$ & $1.220(1)$ \\
\hline$\Sigma$ & 13 & 8 & 14 & 8 \\
\hline$a$ & $0.497(2)$ & $0.481(1)$ & $0.928(2)$ & $0.891(1)$ \\
\hline$b$ & $6.294(2)$ & $6.517(1)$ & $0.542(2)$ & $0.821(1)$ \\
\hline$R^{2}$ & $0.498(1)$ & $0.510(2)$ & $0.939(2)$ & $0.926(1)$ \\
\hline$\underline{\bar{E}}$ & $-0.038(1)$ & $-0.013(2)$ & $-0.003(2)$ & $-0.007(1)$ \\
\hline$\overline{E A}$ & $1.633(2)$ & $1.820(1)$ & $0.910(2)$ & $0.976(1)$ \\
\hline$D P E$ & $2.249(2)$ & $2.324(1)$ & $1.225(2)$ & $1.358(1)$ \\
\hline$R Q M E$ & $2.219(2)$ & 2.293(1) & $1.221(2)$ & $1.355(1)$ \\
\hline$\Sigma$ & 12 & 9 & 14 & 7 \\
\hline
\end{tabular}

${ }^{1}$ Interection (a); Angular Coefficient $(b)$; Coefficient of determination $\left(R^{2}\right)$, Mean of errors $(\bar{E})$; Standard Error Deviation $(D P E)$; Mean of Absolute Errors $(\overline{E A})$; Square Root Mean of Errors (RQME); Root Mean Square of the Standardized Error (RQMEP). 
The maps of the spatial distribution of adults of $T$. limbativentris per $\mathrm{m}^{2}$ interpolated respectively by ordinary kriging and inverse of distance weighted for different crop stages revealed a better delimitation of the zones with population densities for the ordinary kriging interpolator. Where the lines presented an organic behavior, different from that found for the interpolator of the inverse of distance weighted, with straight lines (Figure 1a, b). A negative characteristic of the inverse of distance weighted interpolation method is the generation of a crosshair around the observed points [25]. The targeting effect, when present, can interfere with decision making for localized sampling and pest control.

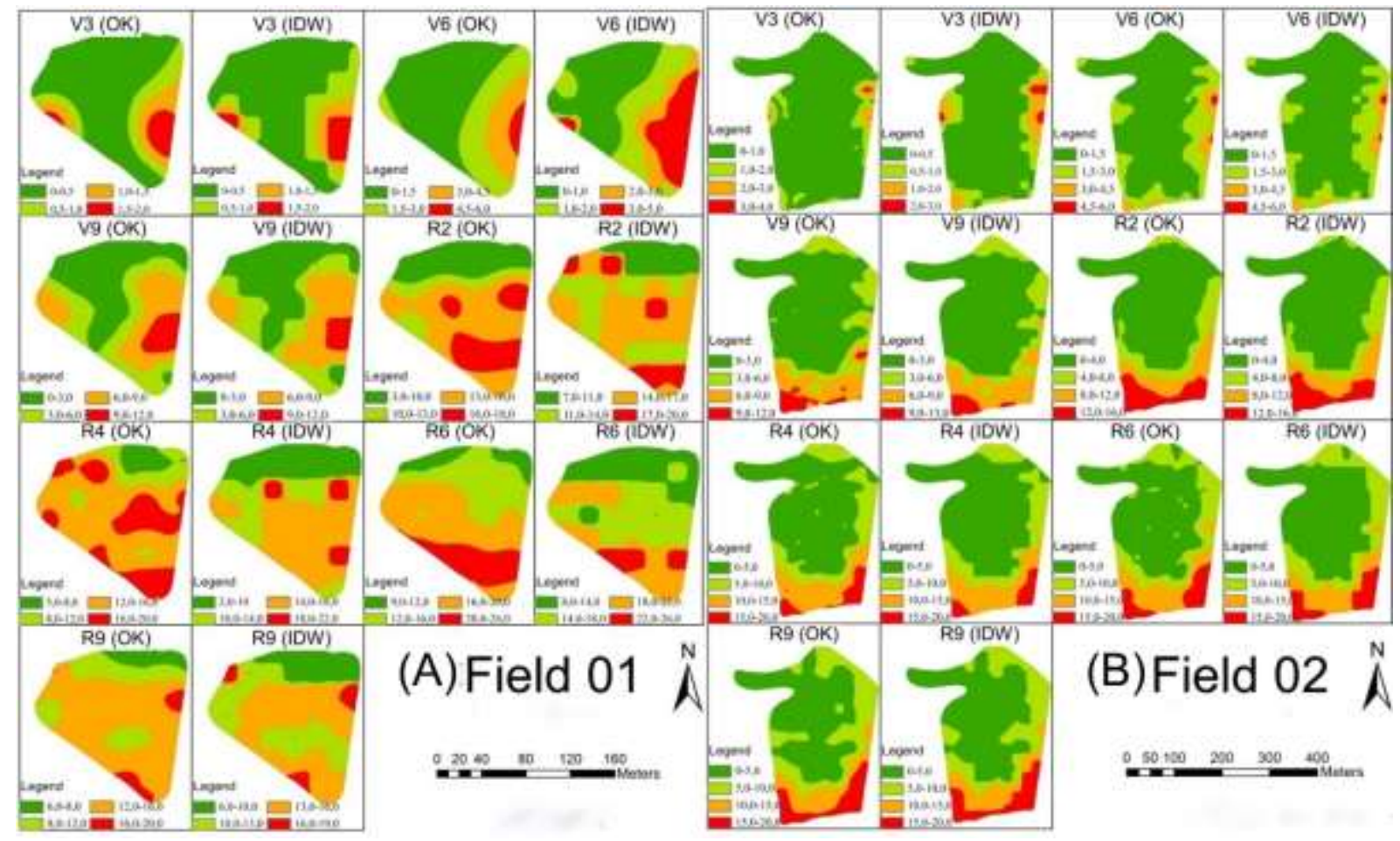

Figure 1. Spatial distribution of Tibraca limbativentris (Hemiptera: Pentatomidae) per $\mathrm{m}^{2}$ interpolated respectively by ordinary kriging (OK) and inverse of the weighted distance (IDW) for different evaluations in Field $01(\mathrm{~A})$ and Field 02 (B).

Finally, the results demonstrate that for spatialization of $T$. limbativentris in irrigated rice, the ordinary kriging interpolator obtained better performance through geostatistical analysis. Thus, it is noted that the ordinary kriging interpolator stood out in relation to the inverse of distance weighted. This suggests that its use in the spatialization of $T$. limbativentris in irrigated rice may be more efficient in making decisions about georeferenced monitoring techniques for this insect pest. Impacting the costs, efficiency and sustainability of its management.

\section{CONCLUSION}

Ordinary kriging interpolation method presents better performance applied in the spatialization of the population density of Tibraca limbativentris in the cultivation of irrigated rice.

\section{REFERENCES}

1. Walter LC, Strecket NA, Rosa HT, Krüger CAMB. Mudanças climáticas e seus efeitos na cultura do arroz. Cienc. Rural, 2010; 50(11): 2411-8. https://doi.org/10.1590/S0103-84782010001100028

2. Sosbai. Arroz Irrigado: Recomendações Técnicas da Pesquisa Para o Sul do Brasil. Porto Alegre: Sosbai, 2012.177p.

3. Oliveira JV, Freitas TFS, Fiuza LM, Menezes VG, Dotto G. Manejo de insetos associados à cultura do arroz irrigado. Cachoeirinha: IRGA, 2010. 56p. (Boletim técnico, 8).

4. Chilès, JP, Delfiner P. Geostatistics modeling spatial uncertainty. Wiley, New York, 1999, 695p.

5. Coelho EC, Souza EG, Uribe-Opazo MA, Neto RP. Influência da densidade amostral e do tipo de interpolador na elaboração de mapas temáticos. Acta Sci. Agron, 2009;31(1):16574.https://doi.org/10.4025/actasciagron.v31i1.6645

6. Silva AF, Lima JSS, Oliveira RB. Métodos de interpolação para estimar o pH em solo sob dois manejos de café 
arábica. Idesia, 2010; 28(2): 61-6. http://dx.doi.org/10.4067/S0718-34292010000200007

7. Mello CR, Lima JM, Silva AM, Mello JM, Oliveira MS. Krigagem e inverso do quadrado da distância para interpolação dos parâmetros da equação de chuvas intensas. Rev. Bras. Ciênc. Solo, 2003;27(5):925-33.

8. Pires CAF, Strieder AJ. Modelagem Geoestatística de dados geofísicos, aplicada a pesquisa de Au no prospecto volta grande (Complexo Intrusivo Lavras do Sul, RS, BRASIL). Rev. Geomática, 2006; 1(1): 1303-11.

9. Miranda, JI. Fundamentos de sistemas de informações geográficas.1. ed. São Paulo: EMBRAPA, 2005.

10. Junior H K, Scolforo JR. De Mello JM, De Oliveira AD. Avaliação de interpoladores estatísticos e determinísticos como instrumento de estratificação de povoamentos clonais de Eucaliptus sp. Cerne, 2006;12(2):123-36.

11. Soares VP, Soares VP, Zaneti LZ, Santos NT, Leite HG. Análise espacial da distribuição de cigarras (Quesada gigas Oliver) em povoamentos de paricá (Schizolobium amazonicum Huber ex Ducke) na região de Dom Eliseu, PA. Rev. Árvore, 2008; 32(2): 251-8. https://doi.org/10.1590/S0100-67622008000200008.

12. Souza GS, Lima JSS, Xavier AC, Rocha WSD. Krigagem ordinária e inverso do quadrado da distância aplicados na espacialização de atributos químicos de um argissolo. Sci. Agr. 2010; 11(1): 73-81. http://dx.doi.org/10.5380/rsa.v11i1.15939

13. Guedes ICL, Mello, JM, Mello CR, Oliveira AD, Silva ST, Scolforo JRS. Técnicas geoestatísticas e interpoladores espaciais na estratificação de povoamentos de Eucalyptus sp. Cien. Florestal, 2012; 22(3): 541-50. https://doi.org/10.5902/198050986621.

14. Heldwein AB, Buriol GA, Streck NA. O clima de Santa Maria. Cien. Amb. 2009; 38: 43-58.

15. Counce PA, Keisling TC, Mitchell AJ. A uniform, objective, and adaptative system for expressing rice development. Crop Sci., 2000; 40(2): 436-43. https://doi.org/10.2135/cropsci2000.402436x.

16. Pasini MBP, Lúcio AD, Filho AC. Semivariogram models for estimating fig fly population density throughout the year. Pesq. Agropec. Bras., 2014; 49(7): 493-505. http://dx.doi.org/10.1590/S0100-204X2014000700001

17. Johnston K, Ver Hoef JM, Krivoruchko K, Lucas N. ArcGIS 9: using ArcGIS geostatistical analyst. Redlands: Esri Press, 2001. 306p.

18. Zimback CRL. Análise espacial de atributos químicos de solo para o mapeamento da fertilidade do solo. Botucatu, UNESP, 2001. 114p. (Tese - Livre Docência).

19. Webster R, Oliver MA. Geostatistics for environmental scientists (2 ed.). John Wiley. \& Sons, Ltd., 2007. 315p.

20. Yamamoto JK, Landim PMB. Geoestatística: conceitos e aplicações. São Paulo: Oficina de textos, 2013, 215p.

21. Grego CR, Vieira SR, Lourenção AL. Spatial distribution of Pseudaletia sequax Franclemlont in triticale under notill management. Sci. Agri., 2006; 63(4): 321-7. https://doi.org/10.1590/S0103-90162006000400002.

22. Dinardo-Miranda LL, Fracasso JV, Costa VP, Lopes DOT. Dispersal of Cotesia flavipes in sugarcane field and implications for parasitoid releases. Bragantia, 2014; 73(2): 163-70. https://doi.org/10.1590/brag.2014.023.

23. Dal Prá E, Guedes JVC, Cherman MA, Jung AH, Silva SJP, Ribas GG. Uso da geoestatística para caracterização da distribuição espacial de larvas de Diloboderus abderus. Cienc. Rural, 2011;41(10):1689-94. https://doi.org/10.1590/S0103-84782011001000002.

24. Silva KR, Cecilio R, Xavier AC, Pezzopane JRM. Interpolação espacial da precipitação no Estado do Espírito Santo. Floram., 2011; 18(4): 417-27. http://dx.doi.org/10.4322/floram.2011.061.

25. Alves EDL, Vecchia FAS. Análise de diferentes métodos de interpolação para a precipitação pluvial no Estado de Goiás. Acta Sci. Human. Soc. Sci., 2011; 33(2): 193-7. http://dx.doi.org/10.4025/actascihumansoc.v33i2.13815.

2021 by the authors. Submitted for possible open access publication under the terms and conditions of the Creative Commons Attribution (CC BY NC) license (https://creativecommons.org/licenses/by-nc/4.0/). 